\title{
Hypertension Factors Analysis of the Denkeslap Kesdam V/Brawijaya Malang
}

\author{
Endri Mustofa \\ Magister of Health Study Program \\ of Institut Ilmu Kesehatan \\ STRADA Indonesia \\ Email: \\ mustofagus@yahoo.com
}

Received : October 12, 2019

Accepted : February 13, 2020

Published : May 12, 2020

\begin{abstract}
Hypertension is a degenerative disease which is a serious problem nowadays. Hypertension is categorized as the silent disease or the silent killer because the sufferer does not know he has hypertension or does not know before checking his blood pressure. The aim of this study was to find out the factors that affected hypertension of the Indonesian Army, Denkeslap Kesdam V / Brawijaya Malang. The research was conducted on 11-14 November 2018 at DENKESLAP Kesdam V / Brawijaya Malang, Observational study design with cross sectional approach. The total population is 65 people and a sample of 56 people with a random sampling technique. Data collection of independent variables and dependent variables by means of observations and questionnaires. Data analysis using logistic regression test. Based on the results of the logistic regression test, the stress variable $p$ value is 0.027 ; anxiety 0.033 and sleep pattern 0.39 at $\alpha: 0.05$, the incidence of hypertension is significantly affected by stress, anxiety and sleep patterns. The dominant factors affecting hypertension are stress. Stress is a condition or condition of the body that is disturbed due to psychological stress. The relationship between stress and the incidence of hypertension occurs through sympathetic nerve activity. Increased nerves can increase blood pressure intermittently (erratic). So that prolonged stress can result in high sedentary blood pressure. Stress will increase peripheral vascular resistance and cardiac output so it will stimulate sympathetic nerve activity. Soldiers are advised to adopt a healthy lifestyle, exercise and maintain a diet, avoiding things that can become stressors so as to minimize hypertension.
\end{abstract}

Keywords: Hypertension, stress, anxiety, sleep patterns

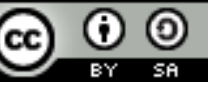

This is an open-acces article distributed under the terms of the Creative Commons Attribution-ShareAlike 4.0 International License. 


\section{INTRODUCTION}

Progress and ease of technology lately days caused many lifestyle changes. Modern people's lifestyle that is all practical and full of ease results in an unhealthy lifestyle, such as lack of physical activity and high consumption of foods containing fat, sodium, and sugar. This has the potential to cause hypertension. Hypertension is a disorder of the blood vessels which results in the supply of oxygen and nutrients carried by the blood blocked to the body tissues carried by the blood (Labarthe, et al., 2015). Hypertension is a manifestation of a disturbance in the cardiovascular system's hemodynamic balance. In general, people are said to be hypertensive if their blood pressure is more than $140 / 90 \mathrm{mmHg}$ (millimeters of Hydragmyrum or millimeters of mercury) (Kaplan, 2012).

Hypertension is now a global problem because its prevalence continues to increase and more and more worrying, it is estimated that in 2025 about $29 \%$ of adults worldwide will suffer from hypertension (Ministry of Health, 2006). Based on data from the AHA (American Heart Association) in 2011, in America out of $59 \%$ of patients with hypertension only $34 \%$ were controlled, it was mentioned that 1 in 4 adults suffer from hypertension (Heidenreich PA, et al, 2011). From the data compiled by the Military Command V / Brawijaya the prevalence of heart and blood vessel disease in 2005 was $13.98 \%$, and the annual report of the Second Level Hospital of Soepraun Malang in 2014, the number of hypertensive sufferers was 291 people consisting of 195 soldiers from territorial unit, 53 people from combat units and the rest are other units. From these data the incidence of hypertension in AD soldiers serving in territorial units was $67 \%$ (rikkes data, 2014). Based on the data list of the 10 largest types of diseases outpatient in 2014 Dr. Ramelan, secondary hypertension ranked third and primary hypertension in seventh with 13,130 patients and 6,061 patients. Data hospitalized in 2014, hypertension ranks fifth out of the 10 biggest diseases in the Dr. Ramelan. In 2014, patients in the TNI category suffered from hypertension and checked their health at the Dr. Ramelan reaches around 3000 patients. About $30 \%$ of outpatients and members of the TNI experience hypertension

Apart from physical activity, the high prevalence of hypertension is also caused by several factors including genetic, and also stress. Stress is related to hypertension. The relationship between stress and the incidence of hypertension occurs through sympathetic nerve activity. Increased nerves can increase blood pressure intermittently (erratic). So that prolonged stress can result in high sedentary blood pressure. Stress will increase peripheral vascular resistance and cardiac output so it will stimulate sympathetic nerve activity (Dewi, 2010).

Stress responses that arise in individuals are behavior, cognitive, physiological, and psychological. Behavioral responses include increased consumption of cigarettes and alcohol, no appetite or overeating, and so on. In cognitive responses include inability to make decisions, difficulty concentrating, sensitivity to threats, and so on. Physiological responses include sleeplessness, headaches, hypertension and so on. Psychological responses such as anger, anxiety, frustration, etc. (Handoyo, 2015). Stress, anxiety and sleep patterns are predicted to be factors causing hypertension. In this study, the individuals who will be studied are Army soldiers. Army personnel include individuals who are rarely researched in research so this research will be interesting and unique. In addition, military units rarely talk about the psychological side of life in the environment which results in hypertension.

\section{METHODS}

The design of this study is the Cross Sectional. The population is TNI soldiers AD Denkeslap Kesdam $\mathrm{V} /$ Brawijaya Malang on 65. The number of samples is 56 respondents using a simple random sampling technique. The dependent variable in this study is hypertension and the independent variables are stress, anxiety and sleep patterns. The instrument in this study used quitionare with logistic regression statistical tests with a significance level of $p$ value $\leq 0.05$.

\section{RESULT}

Table 1 Distribution frekuensi based on stress

\begin{tabular}{cccc}
\hline No. & stress & Frekuensi & Prosentase \\
\hline $\mathbf{1}$ & No stressed & 22 & 39,3 \\
\hline $\mathbf{2}$ & mild stress & 21 & 37,5 \\
\hline $\mathbf{3}$ & Moderate stress & 5 & 8,9 \\
\hline
\end{tabular}




\begin{tabular}{cccc}
\hline $\mathbf{4}$ & Severe stress & 8 & 14,2 \\
\hline & Total & $\mathbf{5 6}$ & $\mathbf{1 0 0}$ \\
\hline
\end{tabular}

Source: Primary data of research in 2018

Based on the data obtained only a small proportion of respondents who experienced moderate stress were 5 respondents $(8.9 \%)$

Table 2 Distribution frekuensi based on anxiety

\begin{tabular}{cccc}
\hline No. & anxiety & Frekuensi & Prosentase \\
\hline $\mathbf{1}$ & No anxiety & 7 & 12,5 \\
\hline $\mathbf{2}$ & Mild anxiety & 12 & 21,4 \\
\hline $\mathbf{3}$ & Moderate anciety & 23 & 41,1 \\
\hline $\mathbf{4}$ & Severe anxiety & 14 & 25,0 \\
\hline & Total & $\mathbf{5 6}$ & $\mathbf{1 0 0}$
\end{tabular}

Based on the research data, some respondents experienced moderate anxiety as many as 23 respondents $(41.1 \%)$

Table 3 Distribution frekuensi based on sleep pattern

\begin{tabular}{cccc}
\hline No. & Sleep patern & Frekuensi & Prosentase \\
\hline $\mathbf{1}$ & normal & 11 & $19,6 \%$ \\
$\mathbf{2}$ & disorder & 45 & $80,4 \%$ \\
\hline & Total & $\mathbf{5 6}$ & $\mathbf{1 0 0}$ \\
\hline
\end{tabular}

Source: Primary data of research in 2018

Based on the research data, almost all respondents experienced a sleep disorder, namely 45 respondents $(80.4 \%)$

\begin{tabular}{cccc}
\hline Table 4 & Distribution frekuensi based on blood pressure & \\
\hline No & Blood pressure & Frekuensi & Prosentase \\
\hline 1 & normal & 25 & 44,6 \\
\hline 2 & hypertension & 31 & 55,4 \\
\hline & & $\mathbf{3 8}$ & $\mathbf{1 0 0}$ \\
\hline
\end{tabular}

Based on research data it is known that more than half of the respondents had hypertension as many as 31 respondents $(55.4 \%)$

Table 5 Wald Test

Variables in the Equation

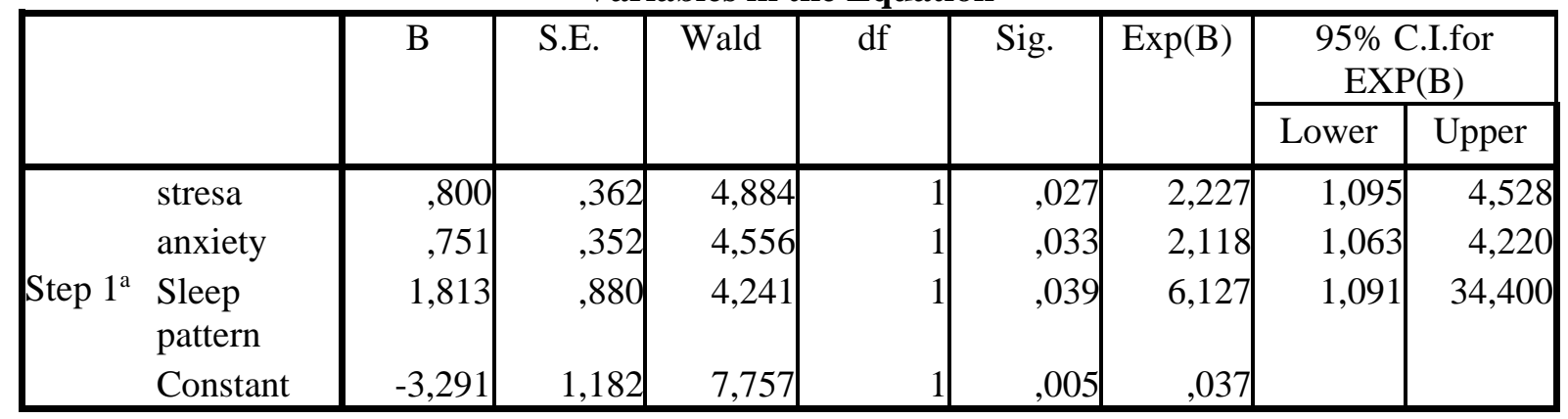

a. Variable(s) entered on step 1: stress, anxiety, sleep pattern

a. Stress (X1)

Wald value is obtained for 4.884 with a significance value of 0.027 where it is smaller than the significance level of 0.05 . Then it can be concluded that the accepted hypothesis is that stress significantly influences hypertension. Denkeslap warriors Kesdam V / Brawijaya Malang. 
b. Anxiety (X2)

Wald value obtained was 4,556 with a significance value of 0,033 which was smaller than the significance level of 0.05 . Then it can be concluded that the hypothesis is accepted, namely anxiety significantly influences hypertension Denkeslap warriors Kesdam V / Brawijaya Malang.

c. Sleep Pattern

Wald value obtained is 4.241 with a significance value of 0.039 which is smaller than the significance level of 0.05 . Then it can be concluded that the accepted hypothesis is that sleep patterns significantly influence hypertension Denkeslap soldiers Kesdam V / Brawijaya Malang.

\section{DISCUSSION}

\section{A. Effect of stress on hypertension Soldier DENKESLAP Kesdam V / Brawijaya Malang}

Based on the results of the Wald test, partially, getting stress has a p-value of 0.027 because the p-value $<\alpha(0.05)$ then $\mathrm{H} 1$ is accepted, so it can be concluded that there is a significant relationship between stress and hypertension. Stress is a condition or condition of the body that is disturbed due to psychological stress and usually stress is associated with psychological illness (Mumpuni, 2011). The relationship between stress and the incidence of hypertension occurs through sympathetic nerve activity. Increased nerves can increase blood pressure intermittently (erratic). So that prolonged stress can result in high sedentary blood pressure. Stress will increase peripheral vascular resistance and cardiac output so it will stimulate sympathetic nerve activity (Dewi, 2010).

Everyone experiences stress from time to time, and generally can adapt long-term stress or face short-term stress until the stress has passed. This condition can cause stress, called a stressor. Internal stressors originate from within a person, for example: fever, infectious disease, physical trauma, malnutrition, physical fatigue, continuous disorder of biological functions. Meanwhile, external stressors come from outside of someone. Examples such as meaningful changes in an environment, changes in roles and social, learning processes, shelter, work and interpersonal relationships

Specifically, the effect of stress on the physiology of the body is on the nervous system. When stressed, the physical and psychological will change the source of energy to the position of preparation for threats, known as the "fight or flight" response. The sympathetic nerve will stimulate the adrenal gland to release adrenaline and cortisol. These hormones will cause the heart to beat faster, increase blood pressure, change the digestive process and glucose levels in the blood. Stress also affects the cardiovascular system, where acute stress causes an increase in heart rate and stronger contractions of the heart muscle. Blood vessels that lead to large muscles and the heart are dilated to increase blood supply. Repeated episodes of acute stress can cause inflammation in the coronary arteries and become a heart attack. The digestive system can also be affected by stress, stress can make the sufferer eat far more or less. If sufferers consume alcohol and cigarettes will also cause heartburn or reflux in the esophagus. In addition, the stomach becomes uncomfortable and can trigger nausea and vomiting, even pain. In the intestine, absorption and peristalsis can occur causing constipation or diarrhea.

Stress on TNI AD soldiers can be influenced by military discipline where generally commanders are absolute (prerogative). Schultz \& Schultz (2016) revealed that leadership patterns are one of the stressors. Individuals will experience distress if they feel they do not have the ability to solve problems that are considered important to him so that they see the problem as a threat. Conversely, individuals will experience eustress if they feel able to solve problems that are considered important so that they see the problem as a challenge that can motivate themselves (Schultz \& Schultz, 2014). Establishing positive and warm relationships with others is inseparable from the ability of a soldier to master his environment. Environmental control in this case relates to the extent to which the soldiers are able to manage various external activities, are able to take advantage of existing opportunities, are able to choose and have the competency to manage the environment that suits their personal needs. Whereas in reality the TNI members cannot choose an environment that matches their personal needs, where the environment of members has been set up or formed in a structured and organized manner. This right can result in the inability of TNI members to develop their own potential to cause stress. Even so, on the other hand the members have demonstrated their ability to manage their external activities, which are a condition for 
physical and psychological pressure as part of the responsibility in realizing peace, maintaining national security and achieving the national development goals of the NKRI.

\section{B. Effect of anxiety on hypertension Soldier DENKESLAP Kesdam V / Brawijaya Malang}

Based on the results of the Wald test partially in getting anxiety has a p-value of 0.033 because p-value $<\alpha(0.05)$ then $\mathrm{H} 1$ is accepted, so it can be concluded that there is a significant relationship between anxiety with hypertension Nevid Jeffrey S, Rathus Spencer A, \& Greene Beverly (2015) provides an understanding of anxiety as an emotional state that has physiological arousal characteristics, unpleasant tense feelings, and concerns that something bad will happen. Anxiety is a feeling of worry, fear that is not clear why. Anxiety is also a big force in moving behavior, both deviant and disturbed behavior. The results of the study are in accordance with previous studies entitled "Relationship to anxiety with the incidence of hypertension in the elderly at the posyandu in the Pundong Bantul Community Health Center working area 2009" Based on the results of the study there was a significant positive relationship between anxiety and hypertension in the elderly, and an effective contribution of $7,07 \%$.

Measurement of anxiety using the Hamilton Anxiety Rating Scale (HARS) questionnaire. The HARS scale is a measure of anxiety based on the appearance of symptoms in individuals who experience anxiety. According to the HARS scale there are 14 syptoms that appear in individuals who experience anxiety. Each observed item is given 5 levels of scores (Likert scale) between 0 (Zero Present) to 4 (severe). The HARS scale was first used in 1959, which was introduced by Max Hamilton and now has become a standard in measuring anxiety, especially in trial clinic research. The HARS scale has been proven to have high validity and reliability to measure anxiety in the clinical trial study of 0.93 and 0.97 . This condition shows that measuring anxiety using the HARS scale will obtain valid and reliable results.

Anxiety serves as a sign of the danger that will occur, a threat to the ego that must be avoided or resisted. In this case the ego must reduce the conflict between the wishes of the Id and the Superego. This conflict will always exist in human life because according to Freud, instincts will always seek satisfaction while the social and moral environment limits the satisfaction. So according to Freud a defense will always operate widely in terms of human life.

Anxiety experienced by respondents in the study was classified as moderate anxiety. Moderate anxiety is anxiety that arises for a moment where it is normal for an individual due to threatening situations and the individual cannot overcome it, resulting in anxiety. This anxiety will be beneficial for individuals to be more careful in facing similar situations in the future.

\section{Effect of sleep patterns on hypertension of DENKESLAP Soldiers in Military District V / Brawijaya Malang}

Based on the results of the Wald test partially in getting the sleep pattern has a p-value of 0.039 because the p-value $<\alpha(0.05)$ then $\mathrm{H} 1$ is accepted, so it can be concluded that there is a significant relationship between sleep patterns and hypertension. The results of this study are in accordance with previous studies by Olivia Rahmadani (2017) where it was found that there was a significant relationship between sleep patterns to blood pressure in high school adolescents at Al-Munawwir Krapyak Islamic Boarding School in Yogyakarta. Most santri have irregular or bad sleep patterns, which are 32 respondents $(71.1 \%)$ and blood pressure in santri with normal-high categories, namely 25 respondents $(55.6 \%)$. The results of the chi square test obtained p-value of $0.033<(0.05)$ therefore preventing hypertension is necessary to maintain a good and sufficient sleep pattern.

Sleep is one of the physiological needs that has an influence on quality and life balance. Someone who experiences a disruption in the sleep cycle, the other physiological functions of the body can also be disrupted or changed. Failure to maintain a normal individual sleep-wake cycle can affect one's health (Potter \& Perry, 2010). Sleep physiology is an arrangement of activities involving the cerebral mechanism. Sleep is a condition where the body is unconscious and does not react to the environment. When sleeping, a person can be awakened again with senses or sufficient stimulation (Potter \& Perry, 2010). Sleep occurs when a person closes his eyes and does not respond to his environment then sleep will end with the return of awareness of the surrounding conditions. Poor sleep quality is a risk factor for physical and psychological problems. Physical 
problems that can be caused include increased glucose levels and are risk factors for cardiovascular disorders such as increased blood pressure in children, adolescents, and adults. Javaheri, Isser, Rosen \& Redline (2008) conducted a study to determine the relationship between poor sleep quality and prehypertension or hypertension in adolescents. Based on these studies it is known that there is a significant relationship between poor sleep quality and prehypertension in adolescents $(\mathrm{p}$ $<0.001)$. Where from the results of these studies there is an increase in systolic and diastolic blood pressure in adolescents who have poor sleep quality.

Respondents in this study were soldiers who were accustomed to rigorous physical training and poor sleep patterns, this is likely to be the cause of hypertension. DENKESLAP Warriors of Military District V / Brawijaya Malang. This is in accordance with Gangwich's discussion (2006) that sleep patterns are one of the risk factors for hypertension. Inadequate sleep patterns and poor quality of sleep can cause physiological and psychological balance disorders in a person. In addition, the duration of short sleep for long periods of time can cause hypertension due to an increase in 24-hour blood pressure and heart rate, increased sympathetic nervous system, and increased salt retention. Furthermore, it will cause structural adaptation of the cardiovascular system so that blood pressure becomes high. The conditions experienced by individuals can affect their sleep patterns, several factors that affect sleep patterns, namely stress, physical environment, diet, drugs, physical exercise, illness, and lifestyle. Changes in age can also affect a person's sleep patterns, actually what happens is not a change in the total amount of sleep, but the quality of sleep that will change, there will be a decrease in REM sleep episodes that will tend to shorten

Slow-wave sleep is a deep sleep condition (stages 3 and 4 or N3 sleep) which is also called "deep sleep" which is characterized by "vagal tone" which is increased activity in the parasympathetic nerve and reduced "sympathetic vagal" which is decreased activity in the sympathetic nerve, and consequently a decrease in heart rate and blood pressure. In addition, deep sleep sleep suppression in humans provides support for the role of deep sleep in glucose homeostasis and nocturnal fluctuations in blood pressure. This shows the low proportion of deep sleep associated with the possibility of hypertension

The relationship between sleep and hypertension occurs due to sympathetic activity in blood vessels so that a person will experience significant changes in cardiac output at night. A decrease in peripheral vascular resistance causes a normal nocturnal decrease in arterial pressure. Sympathetic nerve activity during sleep significantly increases and varies greatly during REM compared to waking up. Blood pressure approaches the level of wakefulness as long as the component in the REM phase is missed, and new sensitivity increases during sleep. However, such conditions are more effective at increasing guarding of blood pressure during REM episodes occurring at the end of the sleep period than the night before. This is related to sleep patterns. Abnormal sleep is involved in the pathogenensis of non-dipping prehypertension and then in hypertensive disorders in sleep quality causes hypertension. This condition occurs because sleep can have an influence on the nervous system and other organs of the human body physiologically. Some components in the body including the nervous system that has been used to carry out various activities, to restore it is necessary to sleep as a means of rest. Sleep also plays a role in the process of protein synthesis, psychologically alone, sleep is also important because someone who has a number of hours of sleep that is not enough will tend to be emotionally irritable, poor concentration, and have difficulty making decisions

\section{Dominant factors that influence hypertension of DENKESLAP in Military District V / Brawijaya Malang}

The results of the study showed that stress was the most influencing factor in the hypertension of the Soldiers of DENKESLAP in the Military V / Brawijaya Malang with a $p$ value of 0.027. Stress makes the brain release stress hormones such as adrenaline, cortisol, and norepinephrine which causes an increase in heart rate and widening of blood vessel diameter. As a result, blood pressure increases by 30-40\% even if only temporarily. This tension increase will not last long, because the heart rate, blood vessel diameter, and blood pressure will return to normal after the stress hormone disappears. People with severe anxiety disorders may not necessarily experience chronic hypertension due to their anxiety. Anxiety is not the cause of long-term hypertension. Even so, a sudden surge in high blood pressure even if it only lasts for a while remains just as dangerous 
as chronic high blood pressure. Damage that occurs in blood vessels, heart and kidneys can also occur in different situations.

This is in accordance with Jefrrey's (2012) theory of stress is the body's non-specific response to any load demands on it. This concept is formulated in General Adaptation Syndrome (GAS). This GAS functions as an automatic response, physical response, and emotional response to an individual. Selye argues that our bodies react equally to various unpleasant stressors, both sources of stress in the form of bacterial microscopy, organism-related diseases, divorce or flooding. The GAS model states that in a stressful state, our body is like a clock with an alarm system that does not stop until the energy runs out

Severe stress is a cause of hypertension, both elderly, young adults and middle age. As a reduced risk of damage to organs such as the kidneys, heart and others can be done by reducing salt consumption, as well as providing motivation to relieve stress or make a comfortable situation that can be conditioned to reduce stress levels for people with hypertension (International journal of hypertension, 2011). American Heart Association (AHA) hypertension which is a medical condition that increases blood pressure for a long time with systolic blood pressure $\geq 140 \mathrm{mmHg}$ and diastolic pressure $\geq 90 \mathrm{mmHg}$. Hypertension is an increase in blood pressure more than $140 \backslash$ $90 \mathrm{mmHg}$ according to the Joint National Committee ( JNC) VII, blood pressure in adults (over 18 years). Hypertension or often referred to as the "silent disease" because sufferers often do not know the symptoms or disorders that are often not realized.

\section{CONCLUSION}

There is influence of stress with hypertension. Soldier DENKESLAP Regional Military V / Brawijaya Malang where the result is $\mathrm{p}$ value $0.027<\alpha=0.05$.

There is an influence of anxiety with hypertension. Soldier DENKESLAP Regional Military V / Brawijaya Malang where the results of $p$ value $0.033>\alpha=0.05$.

There is the influence of sleep patterns with hypertension. Soldier DENKESLAP Kesdam V / Brawijaya Malang where the result is $p$ value $0.039>\alpha=0.05$.

\section{REFERENCES}

Anoraga, Panji. 2012. Manajemen Bisnis. Semarang: PT. Rineka Cipta

Apriliawati, A. (2011). Pengaruh Biblioterapi Terhadap Tingkat Kecemasan Anak Usia Sekolah yang Menjalani Hospitalisasi di Rumah Sakit Islam Jakarta. Nursing Science Jurnal Keperawatan

Aris, 2017, Faktor Risiko Hipertensi Grade II Pada Masyarakat [Tesis], Program Studi Magister Epidemiologi Program Pasca Sarjana Universitas Diponegoro Semarang

Ayu Martiani, Rosa Lelyana, 2012, Faktor Risiko Hipertensi Ditinjau Dari Kebiasaan Minum Kopi (Studi Kasus di Wilayah Kerja Puskesmas Ungaran pada Bulan Januari-Februari 2012), Journal of Nutrition College, Volume 1, Nomor 1, Tahun 2012, Halaman 78-85 Online, http://ejournal-s1.undip.ac.id/index.php/jnc

CDC. 2015. Parasites-ascariasis [diakses 20 September 2018]. Tersedia dari:http://www.cdc.gov/parasites/ascariasis/biology.html

Constantinou, M. (2014). The effect of gestalt play therapy on feelings of anxiety experienced by the hospitalized oncology child.University of South Africa

Corwin, Linda. 2016. Diagnosa Keperawatan.Aplikasi pada Praktek Klinis. Edisi IX. Alih Bahasa: Kusrini Semarwati Kadar. Jakarta: Buku Kedokteran EGC

Gangwisch JE, Heymsfield SB, Boden-Albala B, Buijs RM, Kreier F, Pickering TG, et al. Short Sleep Duration as a Risk Factor for Hypertension: Analyses of the First National Health and Nutrition Examination Survey. Hypertension. 2006;47(5):833-9.

Hasibuan, Malayu S.P. (2014). Manajemen Sumber Daya Manusia, Jakarta: Bumi Aksara.

Hawari, Dadang. 2011. Manajemen Stres Cemas Dan Depresi. Jakarta: FKUI

Indrawati, L. (2013). Pengaruh pemberian terapi aktivitas bermain terhadap tingkat kecemasan anak usia toddler akibat hospitalisasi di ruang rawat inap anak RSUD kota Bekasi Tahun 2013. Jurnal Program Studi S1 Ilmu Keperawatan Sekolah Tinggi Ilmu Keperawatan Medistra Indonesia Bekasi.

Javaheri, S., Isser, S. S., Rosen, L. C., \& Redline, S. (2008). Sleep quality and elevated blood pressure 
in adolescent. Diperoleh dari Http://circ.ahajournals.org/content/11 8/10/1034.full.

Jennifer,Kowalak,. Welsh, Williams. 2011. Buku Ajar Patofisiologi. Alih Bahasa Andry Hartono. Jakarta: Buku Kedokteran EGC

Jeffrey S., Spencer. A. Rathus, dan Greene, Beverly. 2015. Psikologi Abnormal. terjemahan Tim

Psikologi Universitas Indonesia. Edisi Kelima. Jilid 1. Jakarta: Penerbit Erlangga

Kartono. Kartini. 2011. Patologi Sosial 2. Jakarta: Grafindo Persada

Kowalski, Robert. 2010. Terapi Hipertensi: Program 8 minggu Menurunkan Tekanan Darah Tinggi. Alih Bahasa: Rani Ekawati. Bandung: Qanita Mizan Pustaka

Muhammad Hafiz, 2016, Faktor-Faktor Yang Berhubungan Dengan Kejadian Hipertensi Pada

Kelompok Lanjut Usia Di Wilayah Kerja Upt Puskesmas Petangi, program keperawatan UIN

Alauddin, Makassar

Mustamir Pedak. (2009).Metode Supernol Menaklukkan Stres.Jakarta: hikmah Publishing House.

Notoatmodjo, S. 2003. Ilmu Kesehatan Masyarakat. Rineka Cipta:Jakarta

Palmer, O.P., 2013. Higher Pevalence Rate of CHD in "Apple Type of besity" Cases as Compared to "Pear Type Obesity" Cases.Departemen Of General Medicine College Jhalawar. Indian J of Clinical Practice. 23 : 91- 94

Potter, P. A. , \& Perry, A. G. (2010). Fundamental keperawatan edisi 7. Jakarta: Salemba Medika

Quick, J. C., \& Quick, J. D. (2004). Organizational Stress And Preventive Management. USA: McGraw-Hill, Inc

Rivai, Veithzal. 2004. Manajemen Sumber Daya Manusia Untuk Perusahaan,Jakarta: Raja Grafindo Persada

Robbins, P. Stephen. (2008). Perilaku Organisasi. Edisi Sepuluh. diterjemahkan oleh: Drs. Benyamin Molan. Erlangga, Jakarta

Salimar, dan Rahayu S. 2002. Perencanaan Menu untuk Penderita Tekanan Darah Tinggi . PT Panebar Swadaya : Jakarta.

Sopiah. 2008. Perilaku Organisasi, Yogyakarta: Andi

Suyono, Slamet. 2013. Buku Ajar Ilmu Penyakit Dalam. Edisi ke 3. Jakarta: Balai Penerbit FKUI

Tedjasukmana P. 2012. Tata Laksana Hipertensi. Departemen Kardiologi, RS Premier Jatinegara dan RS Grha Kedoya, Jakarta, Indonesia.Udjianti, Wajan. 2011. Keperawatan Kardiovaskular. Jakarta: Salemba Medika.

WHO-ISH. 2011. Hypertension Guideline Committee. Guidelines of the Management of Hypertension.J Hypertension. 2003;21(11): 1983-92

Wijayakusuma, Faktor-faktor Risiko Hipertensi Primer Di Puskesmas Tlogosari Kulon Kota Semarang. Jurnal Kesehatan Masyarakat, Volume 1, nomor 2, Tahun 2012. 